\title{
Risiko ved åpen hjertekirurgi
}

\author{
Åpen hjertekirurgi omfatter ulike prosedyrer som gjennomføres ved hjelp av hjerte-lunge-maskin. Teknolo- \\ giske og medisinske fremskritt har bidratt til å øke sikkerheten og dermed redusere korttidsdødeligheten ved \\ operasjonene, men dette innebærer også at sykere pasienter overlever og følgelig at byrden av postoperative \\ komplikasjoner øker. Derfor er risikoprediksjon av stor interesse innen hjertekirurgi. Denne artikkelen \\ omhandler slike prediksjonsmodeller.
}

\author{
Tone B. Enger \\ Hilde Pleym \\ Roar Stenseth \\ Guri Greiff \\ Alexander Wahba \\ Vibeke Videm \\ vibeke.videm@ntnu.no
}

Cardiac Surgery Outcome Study (CaSOS) ble initiert i 2007 som et tverrfaglig samarbeid mellom Norges teknisk-naturvitenskapelige universitet og St. Olavs hospital (1). Studien tar utgangspunkt i Hjertekirurgidatabasen i Trondheim, hvor pre-, intraog postoperative data registreres prospektivt. Fra 2008 har man også samlet inn en preoperativ blodprøve for senere unders $\varnothing$ kelse av biomarkører. CaSOS omfatter pasienter fra og med år 2000. Pasientenes vitale status per 31.12. 2014 er innhentet via Dødsårsaksregisteret.

Hovedmålet med CaSOS er kartlegging av risikofaktorer og prediksjon av komplikasjoner etter åpen hjertekirurgi samt studere sammenhengen mellom biomarkører og ulike kliniske utfall.

\section{Prediksjonsmodeller}

Risikoprediksjon er av stor interesse innen hjertekirurgien. Den oppdaterte versjonen av The European System for Cardiac Operative Risk Evaluation, EuroSCORE II $(2,3)$ er den mest brukte prediksjonsmodellen på verdensbasis. EuroSCORE ble opprinnelig utviklet for prediksjon av operasjonsdødelighet, definert som død under sykehusoppholdet eller innen 30 dager etter operasjonen. Formålet var bedret kvalitetskontroll og reduksjon av systemsvakheter innen hjertekirurgi. Gjennom å ta høyde for ulike risikoprofiler skal EuroSCORE standardisere sammenligningen av kirurgiske utfall.

I dag brukes risikoalgoritmer også som et tilleggsverktøy når klinikerne skal overveie alternative behandlingsstrategier, gi pasientene $\mathrm{og}$ deres pårørende informasjon om inngrepet og dets risiko samt for å planlegge operasjonsprogram og ressursfordeling. Valg av passende behandlingstype til en gitt pasient er særlig blitt aktualisert av at det kommer nye behandlingsformer.

Den medikamentelle behandlingen blir bedre, og mange åpne hjertekirurgiske inngrep har fått ikke-kirurgiske eller miniinvasive alternativer. Dessuten kan risikoprediksjon bidra til å identifisere behov for spesifikke preoperative risikoreduserende tiltak. Pasienter med økt risiko for postoperativ nyresvikt kan ha behov for preoperativ dialyse, mens pasienter med økt risiko for hjertesvikt kan tilbys preoperativ maskinstøtte (intraaortal ballongpumpe) eller få levosimendan før avgang fra hjerte-lunge-maskinen for å øke kalsiumfølsomheten i hjertet.

Prediksjonsmodeller har også nytteverdi i forskningen, for eksempel ved identifisering av høyrisikopasienter som kan dra nytte av nye behandlingsstrategier og dermed inkluderes i kliniske studier.

Operasjonsdødelighet er det mest brukte endepunktet i eksisterende risikoalgoritmer. Det er et objektivt endepunkt som er sterkt uønsket og som forekommer ved 1,5-4\% av hjerteoperasjonene (3-5). På den annen side er ikke operasjonsdødelighet nødvendigvis en tilstrekkelig markør for behandlingskvalitet eller ressursbruk. Nytteverdien av hjertekirurgi må også ses i lys av postoperative komplikasjoner og livskvalitet.

EuroSCORE har vært testet for prediksjon av blant annet nyresvikt, respirasjonssvikt og hjertesvikt så vel som forlenget opphold i intensivavdelingen og sykehuskostnader, men med varierende resultater (6-10). Risikofaktorer kan være av ulik betydning, og faktorer som påvirker spesifikke morbiditeter, kan mangle i mer generelle modeller. Studier, blant annet fra CaSOS, tyder på at én felles modell for mange endepunkter neppe er mulig $(11,12)$.

\section{Prediksjonsmodeller fra CaSOS}

I CaSOS har man utviklet prediksjonsmodeller for ulike endepunkter, og disse er blitt sammenlignet med tilsvarende eksterne modeller (tab 1) $(2,5,11,13,14)$. Mange klinikere vil hevde at individuell utregning av risikoen for ulike komplikasjoner er for tidkrevende og lite gjennom- førbart i en hektisk hverdag. Økt vektlegging av prediksjon av postoperative komplikasjoner sikter derimot mot en ytterligere forbedring av hjertekirurgiske resultater. Utvalgte modeller fra CaSOS er gjort lett tilgjengelige på nett (15) - et skritt på veien mot anvendelsen av risikoprediksjonsverktøy som digital beslutningsstøtte integrert i elektroniske journalsystemer. Arbeidet med å få utprøvd disse modellene i praksis gjenstår.

Prediksjonsmodeller representerer en generalisering av studiepopulasjonen de ble utviklet fra. CaSOS' design som en enkeltsenterstudie er en viktig begrensning. Selv om moderne metoder for internvalidering reduserer risikoen for såkalt overtilpasning (overfitting), vil modellens treffsikkerhet $i$ andre populasjoner fortsatt avhenge av distribusjonen av risikofaktorer, forekomsten av endepunktet og variasjoner i klinisk praksis.

Mens multisentermodeller kan fungere i flere populasjoner, vil potensialet til enkeltsentermodeller i større grad være lokalt. Til gjengjeld viser lokale modeller ofte bedre treffsikkerhet enn de generelle. Dette var gjennomgående i resultater fra CaSOS $(5,11,13,14)$. Innsikt i en lokal modell bidrar til å belyse viktige forhold som gjelder for den aktuelle populasjonen og retter klinikernes oppmerksomhet mot forhold som er avgjørende i deres målgruppe. Bruk av en lokal versus en internasjonal modell avhenger derfor av formålet. Internasjonale modeller er viktige som standardsettende, mens utvikling av lokale modeller kan være et nyttig supplement som bidrar til lokal kvalitetskontroll.

Grunnet kontinuerlige endringer i risikofaktorer og prevalensen av komplikasjoner forventes det et behov for jevnlig oppdatering av eksisterende modeller. Selv om dette kan ses som en praktisk utfordring, vil nye teknologiske og elektroniske muligheter gjøre arbeidet langt enklere. Dette fremstår som bedre enn stadig å generere nye modeller som ikke blir godt nok utprøvd.

I tillegg til den kliniske verdien av prediksjonsmodeller er det i CaSOS også en 
Tabell 1 Oversikt over variabler inkludert i prediksjonsmodellen fra EuroSCORE II (2) sammenliknet med dem fra Cardiac Surgery Outcome Study (CaSOS) $(5,11,13,14)$. Forkortelser: CCS: Canadian Cardiovascular Society; EuroSCORE: European System for Cardiac Operative Risk Evaluation; NYHA: New York Heart Association Functional

\begin{tabular}{|c|c|c|c|c|c|}
\hline \multirow[b]{2}{*}{ Variabler } & \multirow{2}{*}{$\begin{array}{c}\text { EuroSCORE II } \\
\text { Operasjons- } \\
\text { dødelighet }\end{array}$} & \multicolumn{4}{|c|}{ Casos } \\
\hline & & $\begin{array}{l}\text { Operasjons- } \\
\text { dødelighet }\end{array}$ & $\begin{array}{c}\text { Forlenget } \\
\text { ventilasjon }\end{array}$ & $\begin{array}{c}\text { Hjerte- } \\
\text { dysfunksjon }\end{array}$ & $\begin{array}{c}\text { Akutt } \\
\text { nyresvikt }\end{array}$ \\
\hline
\end{tabular}

\section{Demografiske variabler}

Alder

Kjønn

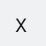

Kroppsmasseindeks

\section{Komorbiditeter}

Insulinavhengig diabetes

Statiner

Perifer karsykdom

Redusert nyrefunksjon

Kronisk lungesykdom

Pulmonal hypertensjon

Hypertensjon

Tidligere hjerteinfarkt

Venstre ventrikkel-hypertrofi

Venstre ventrikkels ejeksjonsfraksjon

Kronisk hjertesvikt

NYHA-klasse

Alvorlig angina pectoris (CCS klasse 4)

Nedsatt mobilitet

\section{Preoperativ operasjonsstatus}

Serum-kreatinin

Kreatininclearance

$x$

Hemoglobin

Hastegrad

Kritisk preoperativ tilstand

Aktiv endokarditt

Tidligere hjertekirurgi

Operasjonstype

Kirurgi på torakale aorta $x$

$x+x$

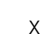

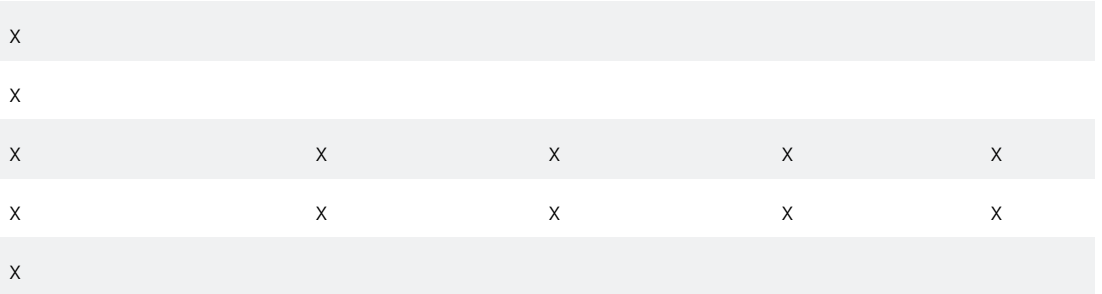

forskningsrettet hensikt: Ved å oppdage nye assosiasjoner mellom risikofaktorer og kliniske utfall bidrar prediksjonsmodeller til å fange opp sammenhenger og frembringe nye hypoteser om bakenforliggende årsaksmekanismer.

\section{Biomarkører}

Selv om de kliniske risikomodellene fra CaSOS og andre sentre viser god prediksjonsevne, gjenstår det individuelle variasjoner i risiko som vi ikke klarer å forutsi. Trolig finnes det en latent eller subklinisk tilbøyelighet til å utvikle komplikasjoner som ikke fanges opp med de kliniske variablene vi har tilgjengelig. Det kan handle om mindre endringer i organfunksjon som bidrar til endret reservekapasitet, variasjoner i molekylære signalveier eller 
bidragsytere til et proinflammatorisk miljø. De subkliniske variasjonene kan få klinisk betydning når kroppen utsettes for en større påkjenning, slik som åpen hjertekirurgi.

Biomarkører er objektive, målbare indikatorer på normale eller unormale biologiske prosesser, en tilstand eller sykdom, og finnes i blod, andre kroppsvæsker eller vev. I CaSOS har man tatt for seg biomarkører i form av genetiske variasjoner og preoperative væskefasemarkører. Utvalget av biomarkører er basert på årsakshypoteser: De er relatert til inflammatoriske eller vaskulære signalveier eller blitt beskrevet som indikatorer for organfunksjon.

Foreløpig har man i CaSOS studert genetiske risikofaktorer for postoperativ blødning og økt perioperativ væskeakkumulering $(16,17)$. Begge representerer endepunkter som er vanskelig å forutsi hvis man bare kjenner kliniske variabler, og funnene viser at kunnskap om en genetisk disposisjon gir økt treffsikkerhet. Det samme gjelder inklusjon av preoperative væskefasemarkører: Preoperativ serum-neopterin var assosiert med høyere risiko for postoperativ hjertedysfunksjon (18). I studien om postoperativ akutt nyresvikt viste det seg at en preoperativ multimarkørtilnærming med neopterin, NT-proBNP, laktoferrin og estimert glomerulær filtrasjonsrate basert på kreatinin og cystatin $\mathrm{C}$ bedret evnen til å identifisere pasienter med økt risiko for postoperativ akutt nyresvikt (19).

Hovedformålet med biomarkøranalysene i CaSOS er ikke å opprette et screeningsprogram med genetiske analyser eller introdusere et nytt panel av serumanalyser som skal gjennomføres preoperativt. Studiene er av en mer forklarende karakter for å utvide forståelsen av underliggende patofysiologi. Hittil har man identifisert biomarkører assosiert med endepunktene, uavhengig av tradisjonelle kliniske variabler. Dette styrker hypotesen om subklinisk sårbarhet.

Videre har biomarkøranalysene understreket den multifaktorielle årsakssammenhengen bak postoperative komplikasjoner, der biomarkører og kliniske variabler avspeiler ulike forhold. Mens hver faktor alene kan utøve kun en mindre effekt på utfallet, er det kombinasjonen av mange faktorer, representert både gjennom kliniske data og biomarkører, som utgjør den totale risiko. Det utelukkes imidlertid ikke at biomarkører i fremtiden kan vise seg å være nyttige også i klinisk sammenheng. Identifikasjon av sentrale patofysiologiske mekanismer kan også bidra til utviklingen av forebyggende tiltak og behandling.

\section{Oppsummering}

Åpen hjertekirurgi er et stort inngrep som setter i gang mange biokjemiske endringer i kroppen. Postoperative komplikasjoner er forårsaket av mange faktorer tilknyttet både pasient og prosedyre. I CaSOS har man utviklet en rekke skåringsalgoritmer for ulike komplikasjoner, i hovedsak basert på preoperative risikofaktorer. Disse er tilgjengelige som nettkalkulatorer som fasiliterer anvendelse i en hektisk klinisk hverdag.

Ikke alle utfall er like egnet for klinisk bruk, men kan være av større verdi i forskningssammenheng. Prediksjonsmodellene har også vist sin nytte i studier av nye biomarkører assosiert med ulike kliniske utfall. Både prediksjonsmodellene og biomarkøranalysene i CaSOS har dermed bidratt til å peke ut potensielle årsaksmekanismer og øke vår forståelse av underliggende patofysiologi.

\section{Tone Bull Enger (f. 1989)}

er cand.med. og stipendiat ved Norges teknisknaturvitenskapelige universitet.

Forfatter har fylt ut ICMJE-skjemaet og oppgir ingen interessekonflikter.

\section{Hilde Pleym (f. 1962)}

er spesialist i anestesiologi, klinikksjef ved Klinikk for anestesi og intensivmedisin, St. Olavs hospital, og førsteamanuesis ved Norges teknisk-naturvitenskapelige universitet. Forfatter har fylt ut ICMJE-skjemaet og oppgir ingen interessekonflikter.

\section{Roar Stenseth (f. 1946)}

er spesialist i anestesiologi, pensjonert overlege ved Avdeling for thoraxanestesi og intensivmedisin, St. Olavs hospital, og tidligere professor ved Norges teknisk-naturvitenskapelige universitet.

Forfatter har fylt ut ICMJE-skjemaet og oppgir ingen interessekonflikter.

\section{Guri Greiff (f. 1964)}

er spesialist i anestesiologi, overlege ved Avdeling for thoraxanestesi og intensivmedisin, St. Olavs hospital, og førsteamanuensis ved Norges teknisk-naturvitenskapelige universitet. Forfatter har fylt ut ICMJE-skjemaet og oppgir ingen interessekonflikter.

\section{Alexander Wahba (f. 1962)}

er spesialist i hjertekirurgi og i thoraxkirurgi, overlege ved Klinikk for thoraxkirurgi, St. Olavs hospital, og professor ved Norges teknisknaturvitenskapelige universitet.

Forfatter har fylt ut ICMJE-skjemaet og oppgir ingen interessekonflikter.

\section{Vibeke Videm (f. 1957)}

er spesialist i immunologi og transfusjonsmedisin, overlege ved Avdeling for immunologi og transfusjonsmedisin, St. Olavs hospital, og professor ved Institutt for laboratoriemedisin, barne- og kvinnesykdommer, Norges teknisknaturvitenskapelige universitet.
Forfatter har fylt ut ICMJE-skjemaet og oppgir følgende interessekonflikter: Hun har mottatt bidrag fra Simon Fougner Hartmann Family Foundation.

Litteratur

1. CaSOS - Cardiac Surgery Outcome Study https://www.ntnu.no/lbk/casos (16.12.2016)

2. Euroscore interactive calculator. http://www.euroscore.org/calc.html (16.12.2016).

3. Nashef SA, Roques F, Sharples LD et al. EuroSCORE II. Eur J Cardiothorac Surg 2012; 41: 734-45.

4. Melberg T, Svennevig JL. Hjertekirurgisk-og koronar intervensjonsstatistikk 2008. Hjerteforum 2010; 23: 9-14

5. Berg KS, Stenseth R, Pleym H et al. Mortality risk prediction in cardiac surgery: comparing a novel model with the EuroSCORE. Acta Anaesthesiol Scand 2011: 55: 313-21.

6. Pinna Pintor P, Bobbio M, Colangelo $S$ et al. Can EuroSCORE predict direct costs of cardiac surgery? Eur J Cardiothorac Surg 2003; 23: 595-8.

7. Nilsson J, Algotsson L, Höglund P et al. EuroSCORE predicts intensive care unit stay and costs of open heart surgery. Ann Thorac Surg 2004; 78 1528-34

8. Hirose $H$, Inaba $H$, Noguchi $C$ et al. EuroSCORE predicts postoperative mortality, certain morbidities, and recovery time. Interact Cardiovasc Thorac Surg 2009; 9: 613-7.

9. Messaoudi N, De Cocker J, Stockman BA et al. Is EuroSCORE useful in the prediction of extended intensive care unit stay after cardiac surgery? Eur J Cardiothorac Surg 2009; 36: 35-9.

10. Geissler HJ, Hölzl P, Marohl S et al. Risk stratification in heart surgery: comparison of six score systems. Eur J Cardiothorac Surg 2000; 17: 400-6.

11. Widyastuti Y, Stenseth R, Pleym H et al. Pre-operative and intraoperative determinants for prolon ged ventilation following adult cardiac surgery. Acta Anaesthesiol Scand 2012; 56: 190-9.

12. Widyastuti Y, Stenseth R, Wahba A et al. Length of intensive care unit stay following cardiac surgery: is it impossible to find a universal prediction model? Interact Cardiovasc Thorac Surg 2012; 15 825-32.

13. Widyastuti Y, Stenseth R, Berg KS et al. Preoperative and intraoperative prediction of risk of cardiac dysfunction following open heart surgery. Eur J Anaesthesiol 2012; 29: 143-51.

14. Berg KS, Stenseth R, Wahba A et al. How can we best predict acute kidney injury following cardiac surgery?: a prospective observational study? Eur J Anaesthesiol 2013; 30: 704-12.

15. Det medisinske fakultet, Norges teknisk-natur vitenskapelige universitet. Risikokalkulatorer. https://vev.medisin.ntnu.no/risikokalk/ (16.12.2016).

16. Greiff G, Pleym H, Stenseth R et al. Genetic variation influences the risk of bleeding after cardiac surgery: novel associations and validation of previous findings. Acta Anaesthesiol Scand 2015; 59 $796-806$

17. Enger TB, Pleym H, Stenseth $R$ et al. Genetic and clinical risk factors for fluid overload following open-heart surgery. Acta Anaesthesiol Scand 2014; 58: 539-48

18. Berg KS, Stenseth R, Pleym H et al. Neopterin predicts cardiac dysfunction following cardiac surgery. Interact Cardiovasc Thorac Surg 2015; 21 : 598-603

19. Enger TB, Pleym H, Stenseth R et al. A preoperative multimarker approach to evaluate acute kidney injury following cardiac surgery. J Cardiothorac Vasc Anesth 2016. E-publisert 11.10.2016.

Mottatt 19.5. 2016, første revisjon innsendt 10.10. 2016, godkjent 16.12. 2016. Redaktør: Liv-Ellen Vangsnes. 